\title{
DOI 10.26886/2414-634X.3(47)2021.1
}

UDC: 657

\section{THE PROFESSION OF "ACCOUNTANT" - FROM CRAFT TO MODERN SCIENCE}

\section{Danylyuk, PhD of Economical Sciences}

http://orcid.org/0000-0002-5090-0926

e-mail: irynadanylyuk9@gmail.com

\section{Shuhmann, student}

http://orcid.org/0000-0002-1427-3312

e-mail: vadum.shuhmann@gmail.com

West Ukrainian National University Ukraine, Ternopil

In the context of exacerbation of socio - economic problems and a global pandemic, when there is a mass closure of enterprises, the profession of accountant is not losing its popularity. The article considers the evolution of the profession, identifies the features, areas of activity in the enterprise management system, functions, list of basic requirements for professionals, proposes measures to strengthen the image of the accounting profession.

Key words: profession, accountant, transformation, globalization, digitalization, functions, international standards, activity.

Кандидат економічних наук, доцент, І. Данилюк; студент, В. Шухманн. Профресія «бухгалтер» - від ремесла до сучасної науки / Західноукраїнський національний університет, Україна, Тернопіль

В умовах загострення соціально - економічних проблем та всесвітньої пандемії, коли відбувається масове закриття підприємств, профресія бухгалтера не втрачає своєї популярності. $B$ статmі розглянуто еволюція розвитку профресії, визначено ознаки, сорери діяльності в системі управління підприємством, функції, 
перелік основних вимог, що ставляться до фрахівців, запропоновано заходи які сприяють зміцненню іміджу бухгалтерської профресії.

Ключові слова: профресія, бухгалтер, трансфрормація, глобалізація, діджиталізація, фрункції, міжнародні стандарти, діяльність.

Вступ та постановка проблеми. Розвиток економіки повинен забезпечувати розвиток суспільства в цілому, сприяти підвищенню рівня соціальної захищеності населення. У зв'язку з цим представники облікової профресії визнають необхідність проведення змін на регуляторному рівні з метою наближення завдань бухгалтерського обліку до суспільних інтересів.

Сучасна бухгалтерська професія - продукт постіндустріальної економіки, який підтримується переважно приватним капіталом. При цьому вона зазнає впливу усіх явищ, притаманних економіці в цілому. Ця професія стає дедалі складнішою для опанування. Тому набувають актуальності питання, пов'язані з підготовкою кадрів, зорієнтованих на майбутній розвиток бухгалтерського обліку.

Еволюція поглядів за сформульованою тематикою характеризується як широкими часовими рамками, так і ступенем розкриття суміжних проблем. Систематичне вивчення наукової літератури з даної проблеми показало, що безпосередньо в такій постановці вона не ставилась і не вирішувалась. Разом з тим, є значна кількість публікацій зі споріднених аспектів, які за тематичною спрямованістю можна згрупувати наступним чином:

- значення бухгалтерської професії в умовах глобалізації та постіндустріальної економіки;

-фрункції бухгалтера та сфрера його діяльності;

-діяльність громадських професійних організацій; 
-регулювання бухгалтерської професійної діяльності та етика бухгалтера;

-підготовка бухгалтерських кадрів в системі вищої освіти.

Вирішення теоретичних та практичних проблем бухгалтерського обліку як професійної діяльності дозволить удосконалити інформаційний процес на підприємстві та підвищить престиж бухгалтерської професії у суспільстві.

Аналіз останніх досліджень та публікацій. Дослідженнями в означеному напрямку займалися провідні науковці, зокрема: Ф. Бутинець, Б. Валуєв, Л. Кіндрацька, О. Мазіна, Н. Малюга, Є. Мних, 3. Пестовська, О. Петрук, Н. Правдюк, Я. Соколов, М. Пушкар, Л. Чижевська та ін. Роботи зазначених вчених розкривають не лише зміст та значення бухгалтерського обліку з позиції теорії і практики, а також процес трансформації функцій бухгалтерського обліку, інституту професійних бухгалтерів в постійних змінних умовах ринкового середовища. Однак, неординарні події, що відбуваються останнім часом в економіці України (всесвітня пандемія, падіння промислового виробництва, відтік інвестицій з країни, процеси діджиталізації тощо) вимагають подальшого дослідження з визначеної теми.

Метою статті є дослідження глобалізаційних процесів впливу на профресію бухгалтера, осучаснення останньої за допомогою визначення ролі, фрункцій, вимог, що висуваються суспільством та закріплення іміджу в умовах загострення соціально - економічних проблем.

Результати дослідження. Фактично відійшли в минуле такі синоніми слова “бухгалтер”, як рахівник, обліковець. Все частіше бухгалтер позиціонується як діловий лідер, порадник управлінця, корпоративний фрінансист, фрінансовий директор. У спільноті 
бухгалтерів на світовому рівні перевага надається терміну “профресійний бухгалтер".

Кодекс етики професійних бухгалтерів, прийнятий Міжнародною Федерацією Бухгалтерів, наводить наступні визначення [9, с. 18]: профресійні бухгалтери - особи, які $€$ суб’єктами професійної бухгалтерської практики (зокрема, самостійні профресійні бухгалтерипрактики, партнерство чи корпорація), які зайняті у промисловості, торгівлі, державному секторі чи освіті і $€$ членами організації Міжнародної Федерації Бухгалтерів.

Таким чином, профресіоналізм передбачає володіння комплексом спеціальних теоретичних знань і практичних навиків, набутих у результаті спеціальної підготовки, досвіду роботи. На жаль, практична робота часто призводить до вузької спеціалізації бухгалтера, що, безумовно, знижує його професійний кругозір.

3 наведених визначень можна виділити відмінні ознаки бухгалтерської профресії:

- підвищений суспільний інтерес до наслідків діяльності профресіонала;

- необхідність дотримання етичних цінностей (бухгалтер повинен дотримуватися норм професійної етики, щоб захищати інтереси суспільства);

- монопольні позиції, зокрема, при підтвердженні фрінансових звітів. Згідно з 4-ю, 7-ю і 8-ю Директивами ЄС тільки сертифіковані аудитори вповноважені засвідчувати звіти підприємств. У Греції судовою експертизою можуть займатися тільки сертифіковані аудитори;

- наявність конкуренції всередині професії, що спричиняє конфрлікти; 
- висока професійна мобільність, внаслідок якої особи 3 бухгалтерською освітою обіймають інші економічні або фрінансові посади;

- відносно низька міжнародна міграція внаслідок того, що предмет діяльності залежить від національного законодавства;

- умови реалізації бухгалтерської профресії: бухгалтер може здійснювати свою діяльність як наймана особа у штаті підприємства або як незалежний профресіонал;

- сфрера незалежної діяльності охоплює надання широкого спектру платних послуг з проведення аудиторських перевірок, оподаткування і консультування;

- прагнення до мультидисциплінарності знань (не тільки економічних, але й, зокрема, соціологічних, екологічних);

- вимога до формального та безперервного навчання: те, що відрізняє професіональних бухгалтерів від інших носіїв профресії, - це вимога постійно підтримувати профресіоналізм, а не просто заявляти про одноразову кваліфрікацію;

- забезпечення конфріденційності при роботі з клієнтами;

- автономність і саморегульованість професії;

- суттєва зміна змісту роботи при зміні робочого місця (галузь діяльності, організація бухгалтерської служби відрізняються на різних підприємствах);

- ідентичність завдань (під цим розуміють виконання 3 чітким ромежуванням початку й кінця, наприклад, скласти квартальний звіт);

- державний контроль. Якість виконання обов'язків контролюється як з боку замовників (власників, директорів), так і з боку державних органів (податкової служби, соціальних органів);

- відносно низька кількість відряджень.

Бухгалтер сучасного підприємства виконує функції планового, 
економічного, маркетингового, юридичного відділів. Це потребує принципово нового підходу до підготовки бухгалтерських кадрів та перегляду функцій бухгалтера (рис. 1).

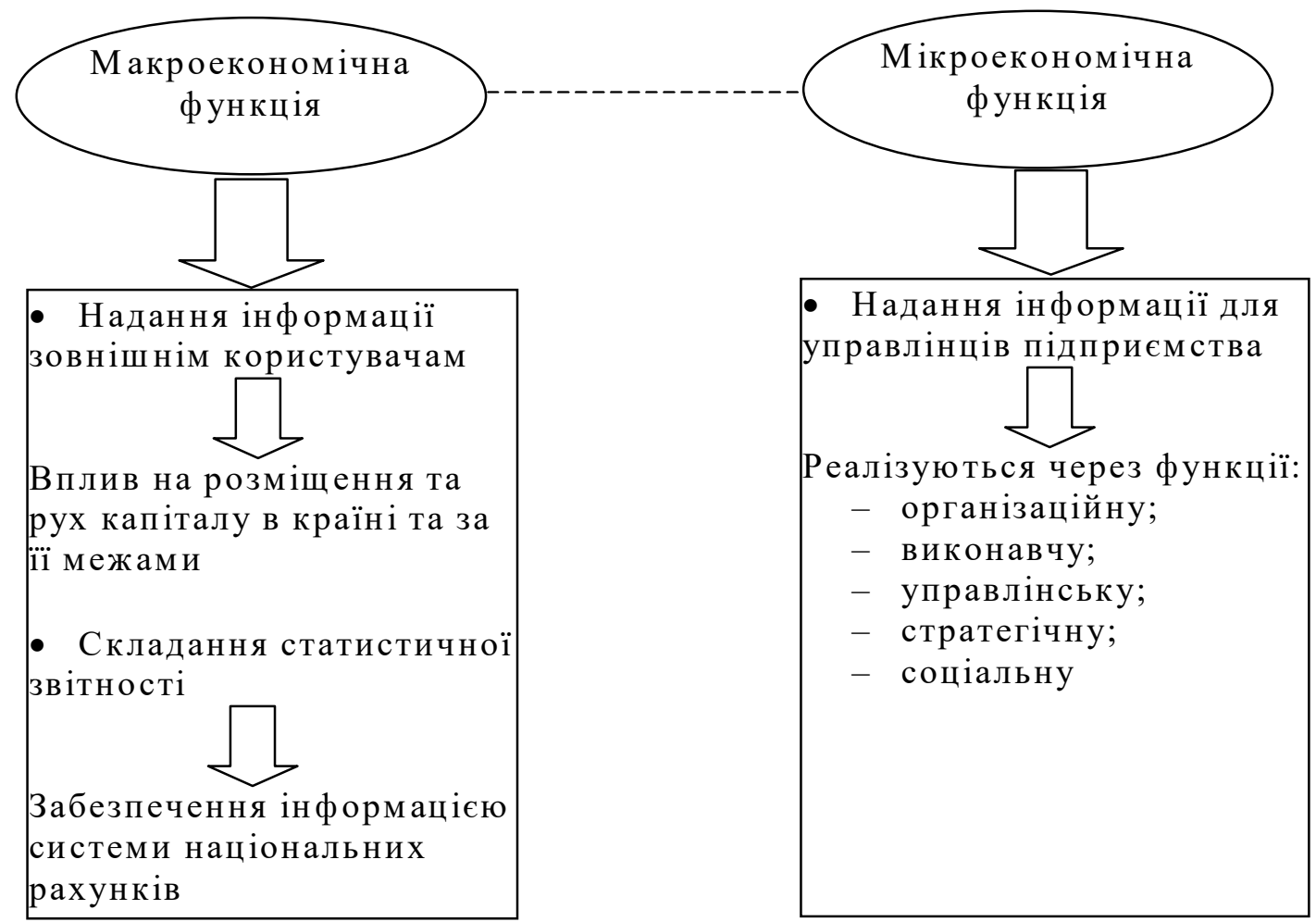

\section{Рис. 1. Функції бухгалтера за роллю в економіці}

У зв'язку з цим функції бухгалтера пропонуємо класифікувати на макроекономічні та мікроекономічні. Макроекономічна функція полягає у наданні зовнішнім користувачам (інвесторам, кредиторам, акціонерам, економічним агентам, суспільству в цілому) інформації про діяльність підприємства. Цим самим бухгалтер впливає на розміщення та рух капіталу в країні або за її межами.

Наступним проявом макроекономічної функції $€$ складання статистичної звітності, що забезпечує інформацією систему національних рахунків, а через це - характеристику економічного життя країни в цілому.

Мікроекономічні фрункції бухгалтера проявляються через надання інформації для керівників підприємства з метою управління ним. При 
цьому бухгалтер-професіонал спрямовує свої зусилля на здійснення спеціальних внутрішніх процедур.

Функції бухгалтера можуть відрізнятися від фрункцій бухгалтерського обліку, оскільки на них впливають такі чинники:

1) рівень кваліфрікації;

2) професійний досвід;

3) організаційні та інші індивідуальні здібності бухгалтера;

4) вимоги нормативних документів і внутрішніх положень підприємства.

На практиці бухгалтер не завжди усвідомлює власні функції, а керівники не завжди знають ті завдання, які вони можуть ставити перед бухгалтером. 3'ясування цих функцій дасть змогу удосконалити організацію бухгалтерського обліку на підприємстві.

Поглибити дослідження функцій бухгалтера дозволяє вивчення історичного аспекту питання.

У працях дослідників встановлені такі основні події та тенденції у розвитку бухгалтерської професії:

1)вперше на посаду бухгалтера за наказом Максиміліана призначено Христофрора Штехера 13 лютого 1498 р.;

2)період Середньовіччя характеризується літературним оформленням бухгалтерського обліку. 3'являються такі праці, як “Про торгівлю і досконалого покупця” В. Котрулі (1458р., Італія), “Трактат про рахунки та записи" Луки Пачолі (1494р., Італія), “Англійська система рахівництва" Т.Джонса (1794р., Англія), “Керівництво для купця та бухгалтера" і “Наука негоціанта" М. Де ля Порта (1673р., Франція) та інші. Ці твори базувалися на тому, що облікове мистецтво недостатньо розглядати як ремесло, а потрібно вбачати в ньому справжню науку. Облік у цей період вівся торговцями та супроводжувався веденням облікових книг; 
3)період кінця XIX - початку XX-го століть характеризується юридичним офрормленням профресії в громадські організації.

Відштовхуючись від наявних історичних досліджень прослідкуємо трансформацію бухгалтерської професії не за хронологічними подіями, а за функціями, що виконувалися бухгалтерами. Такий підхід надасть змогу виявити тенденції і спрогнозувати подальший розвиток функцій бухгалтера.

1. Обліковими працівниками були представники різних професій, що, як правило, стало наслідком поширеної думки в суспільстві про те, що облік - це ремесло, яке не потребує особливих знань. Така позиція стримувала розвиток бухгалтерського обліку як науки.

2. Профресія бухгалтера постійно розвивається. Зміни відбуваються як у функціях, які виконуються представниками бухгалтерської профресії, так і в змісті робіт. Розвиток економічних відносин, технічних засобів, інформаційних технологій призвів до того, що найзначніші зміни відбулися саме у змісті професії бухгалтера.

3. Бухгалтери змінюються під впливом вимог суспільства. Функції бухгалтера змінюються як в межах підприємства, так і суспільства. Розподіл функцій власника й управлінця сприяв зміні функцій бухгалтера в частині надання звітності не лише суб'єктам управління, але й інвесторам, кредиторам та іншим зовнішнім користувачам.

4. Основними чинниками, що сприяли становленню бухгалтерської профресії як суспільно значимої, виступають:

- відокремлення власника від безпосереднього управління бізнесом;

- зростання ролі інформації як стратегічного ресурсу на ринку;

- зміна та розвиток соціально-економічних відносин.

Традиційне трактування функцій бухгалтера, що полягало виключно у веденні рахунків, складанні регістрів і звітності, на 
сучасному етапі не $є$ повним. Сьогодні, коли інформаційне забезпечення стало найважливішим чинником успішної господарської діяльності, функції бухгалтера зазнали суттєвих змін (табл. 1).

Таблиця 1

\section{Функції бухгалтера за роллю в системі управління підприємством}

\begin{tabular}{|c|c|c|c|c|}
\hline Організаційна & Виконавча & Управлінська & Стратегічна & Соціальна \\
\hline 1) організація & 1) ведення & 1) управління & 1) розробка & 1) забезпечен \\
\hline бухгалтерськог & бухгалтерсько & якістю & нових фрорм & ня соціальних \\
\hline о обліку, & го обліку; & інфрормаційних & обліку та & виплат і \\
\hline включаючи & 2) реалізація & послуг; & внутрішньої & доходів \\
\hline підбір і & управлінських & 2) контроль; & звітності; & працівникам \\
\hline розподіл праці & рішень; & 3) керівництво & 2) планування & та акціонерам \\
\hline між & 3) підтриманн & колективом & потреби в & підприємства; \\
\hline бухгалтерськи & Я & бухгалтерських & ресурсах; & 2) захист \\
\hline ми & корпоративної & працівників; & 3) планування & членів \\
\hline працівниками; & культури та & 4) використанн & розвитку & суспільства \\
\hline 2) вибір & сприятливого & я есрективних & бухгалтерсько & через сплату \\
\hline комп'ютерних & соціально- & систем & ї служби & податків і \\
\hline інформаційних & психологічног & мотивації та & & надання \\
\hline систем; & о клімату в & оплати праці; & & достовірної \\
\hline 3) розробка & колективі & 5) профрілактик & & інформації \\
\hline облікової & & а конфрліктних & & про діяльність \\
\hline політики & & ситуацій і & & підприємства \\
\hline підприємства & & вирішення & & \\
\hline & & конфрліктів & & \\
\hline
\end{tabular}

Таким чином має місце невідповідність існуючих функцій бухгалтера, які зорієнтовані на внутрішні фрункції обліку шляхом виконання процедур технічного узагальнення інформації, вимогам управлінця, яке очікує аналітично-стратегічних висновків про діяльність підприємства від бухгалтера, та вимогам суспільства, яке вбачає в бухгалтерських діях захист соціальних інтересів людини. 
Зміст розглянутих функцій бухгалтера наочно свідчить, що реалізація кожної з них залежить від правової культури виконавців, їх кваліфрікації та компетентності. У ході організації бухгалтерського обліку, зокрема, розподілі обов'язків між працівниками слід враховувати ці функції.

Розширення функцій бухгалтера необхідне для забезпечення фрункціонування цілісної системи управління. При цьому розширення функцій бухгалтера не є механічним об'єднанням знань і навиків, які вимагаються від представників інших профресій. Розширення функцій бухгалтера передбачає діалектичне поєднання професійних знань, навиків, компетенцій, цінностей, суміжних спеціальностей. Відбувається своєрідний перерозподіл знань і навиків. Такий підхід забезпечить посилення взаємозв'язку бухгалтерського обліку 3 плануванням, контролем, аналізом. На необхідності такого посилення наголошує проф. Б.І. Валуєв [14].

Дослідження генезису функцій бухгалтера дає можливість виділити такі етапи їх становлення:

1) поява вільної професії, яка надавала можливість продавати свої послуги;

2) стандартизація та масовість професії, ініційована промисловим переворотом і серійним виробництвом, самоорганізація професії;

3) зростання професійної мобільності бухгалтерів, які можуть працювати в різних сфрерах господарювання.

У запропонованій класифікації функцій бухгалтера науково обґрунтовані та враховані конкретні характеристики суті функції [17]:

1) кожна з фрункцій складає відносно самостійну ділянку роботи бухгалтерського персоналу; 
2) назви ффункцій у повній мірі відповідають меті та змісту бухгалтерського обліку;

3) здійснення кожної фуннції є процесом праці, що сфрормувався в результаті поділу та спеціалізації праці;

4) здійснення кожної функції ефективне у єдності та взаємодії 3 усіма іншими;

5) названі ффункції складають основу для фрункцій окремих посадових осіб, і зокрема, головного бухгалтера. У цьому полягає практичне значення даної розробки.

6) вперше фрункції бухгалтера розглядаються за значенням бухгалтерського обліку для економіки, а також за роллю суб'єкта бухгалтерського обліку;

7) при формуванні функцій бухгалтера показано системний характер цих функцій, що обумовлено системністю бухгалтерського обліку;

8) зміст функцій відповідає визначеному комплексу завдань, які вирішуються в процесі управління;

9) у назві кожної фрункції відображено характерні особливості, властиві суб'єкту і об'єкту бухгалтерського обліку. Кожна функція сфрормована під спільним впливом особливостей об'єкта і суб'єкта управління;

10) при визначенні функцій бухгалтера враховувався критерій економічності бухгалтерського обліку (перевищення вигід від управлінського рішення, прийнятого на підставі бухгалтерської інформацій, над витратами, понесеними на збір такої інформації). 
Функції бухгалтерських працівників змінилися від процедурних до управлінських, тому що прийняття обґрунтованих управлінських рішень неможливе без обліково-аналітичної інфрормації. Це вимагає від лідерів, які розуміють нюанси технічних стандартів звітності, дотримуватись високих стандартів якості професійної діяльності.

Перелік основних вимог, які висувають працедавці при прийнятті на роботу бухгалтера (табл. 2).

Таблиця 2

\section{Вимоги працедавців до бухгалтерів}

\begin{tabular}{|c|c|c|}
\hline Вимоги / черги & Вимоги II черги & Вимоги III черги \\
\hline $\begin{array}{l}\text { Вища освіта за } \\
\text { спеціальністю }\end{array}$ & $\begin{array}{l}\text { Вміння виявляти альтернативи та } \\
\text { шляхи вирішення ситуації }\end{array}$ & Комунікативні навики \\
\hline $\begin{array}{l}\text { Практичний досвід роботи } \\
\text { бухгалтером }\end{array}$ & $\begin{array}{l}\text { Надання допомоги власнику й } \\
\text { керівнику підприємства у виборі } \\
\text { оптимального управлінського } \\
\text { рішення }\end{array}$ & $\begin{array}{l}\text { Підбір і встановлення } \\
\text { комп'ютерної } \\
\text { бухгалтерської } \\
\text { програми }\end{array}$ \\
\hline $\begin{array}{l}\text { Високий рівень знань } \\
\text { бухгалтерського обліку, а } \\
\text { також достатній } 3 \\
\text { фінансового менеджменту }\end{array}$ & $\begin{array}{l}\text { Донесення результатів своєї } \\
\text { роботи в доступному для } \\
\text { користувача вигляді }\end{array}$ & $\begin{array}{l}\text { Вміння складати } \\
\text { посадові інструкції для } \\
\text { працівників } \\
\text { бухгалтерської служби } \\
\text { та надавати їм } \\
\text { методичну допомогу }\end{array}$ \\
\hline $\begin{array}{l}\text { Вміння працювати } 3 \\
\text { комп'ютерними } \\
\text { бухгалтерськими } \\
\text { програмами }\end{array}$ & Знання іноземних мов & $\begin{array}{l}\text { Здійснення договірної } \\
\text { роботи на підприємстві } \\
\text { та заходів досудового } \\
\text { вирішення спорів }\end{array}$ \\
\hline $\begin{array}{l}\text { Вміння розпоряджатися } \\
\text { грошовими коштами } \\
\text { підприємства }\end{array}$ & $\begin{array}{l}\text { Вміння відстоювати позицію } \\
\text { підприємства в податкових } \\
\text { органах }\end{array}$ & $\begin{array}{l}\text { Організація служби } \\
\text { внутрішнього контролю }\end{array}$ \\
\hline $\begin{array}{l}\text { Вміння працювати з } \\
\text { нормативними } \\
\text { документами }\end{array}$ & $\begin{array}{l}\text { Знання особливостей ведення } \\
\text { обліку й складання звітності в } \\
\text { країнах-партнерах, вміння } \\
\text { порівнювати звітність свого } \\
\text { підприємства зі звітністю інших }\end{array}$ & $\begin{array}{l}\text { Вміння планувати } \\
\text { витрати і доходи }\end{array}$ \\
\hline
\end{tabular}




\begin{tabular}{|l|l|l|}
\hline $\begin{array}{l}\text { Здатність до аналітичної } \\
\text { роботи }\end{array}$ & $\begin{array}{l}\text { Вміння трансформувати звітність } \\
\text { з одного формату в інший }\end{array}$ & $\begin{array}{l}\text { Наявність сертифікату } \\
\text { професійної організації }\end{array}$ \\
\hline Готовність до сприйняття & Вміння складати фрінансову & Наявність водійських \\
нових знань & звітність відповідно до \\
& $\begin{array}{l}\text { міжнародних стандартів } \\
\text { фінансової звітності }\end{array}$ & \\
\hline
\end{tabular}

$€$ випадки, коли професіоналізм бухгалтера вимірюється одним критерієм - відсутністю штрафрних санкцій 3 боку контролюючих органів.

Дедалі частіше до бухгалтера висувається вимога наявності сертифрікату CAP, CIPA, ACCA, проте це ще не набуло широкого розповсюдження в Україні. 3 боку суспільства ці вимоги висуваються до всіх членів профресійного співтовариства та формують еталон професіонала, відображаючи те, що він повинен знати, про що мати уявлення і якими якостями володіти.

Також спостерігаються тенденції до тестування бухгалтерів не за професійними знаннями, а за внутрішніми якостями: застосування творчого підходу при вирішенні проблем; лідерські якості; вміння навчити інших; гнучкість мислення; ступінь прийняття корпоративної культури.

Зростання обсягів проектного бізнесу та необхідність ефективного управління ним зумовлює створення міжфункціональних робочих команд. А тому зрозумілою $є$ вимога до бухгалтера - вміння працювати у команді.

Найактуальнішими $є$ вимоги, щодо володіння комп'ютерною технікою іноземною мовою, комунікативними навиками, що пояснюється зростаючою роллю бухгалтерів під час ведення переговорів. 
Виявлені вимоги дають змогу запропонувати таку систему заходів щодо посилення професіоналізму бухгалтера (рис. 2).

Держава

\begin{tabular}{|c|c|}
\hline $\begin{array}{c}\text { Закріплення на } \\
\text { законодавчому рівні } \\
\text { відповідальності } \\
\text { бухгалтера й аудитора }\end{array}$ & $\begin{array}{c}\text { Упорядкування } \\
\text { нормативної } \\
\text { бази } \\
\text { бухгалтерськогс } \\
\text { обліку }\end{array}$ \\
\hline $\begin{array}{c}\text { Встановлення обов'язкової } \\
\text { вимоги до освітньо- } \\
\text { кваліфікаційного рівня } \\
\text { бухгалтера }\end{array}$ & \\
\hline $\begin{array}{c}\text { Розробка системи } \\
\text { підтримки високої } \\
\text { працездатності } \\
\text { бухгалтерів }\end{array}$ & \\
\hline $\begin{array}{c}\text { Дотримання моральних } \\
\text { цінностей вищим } \\
\text { управлінським } \\
\text { персоналом }\end{array}$ & $\begin{array}{c}\text { Здійснення } \\
\text { інвестицій у } \\
\text { людський } \\
\text { капітал }\end{array}$ \\
\hline
\end{tabular}

Суб'єкти підприємницької діяльності
Професійні організаиії

\begin{tabular}{|c|c|}
$\begin{array}{c}\text { Розробка } \\
\text { системи } \\
\text { безперервної } \\
\text { освіти }\end{array}$ & $\begin{array}{c}\text { Забезпечення контролю } \\
\text { за дотриманням } \\
\text { суспільних інтересів у } \\
\text { діяльності бухгалтерів і } \\
\text { аудиторів }\end{array}$ \\
$\begin{array}{c}\text { Розробка технічних } \\
\text { стандартів ведення } \\
\text { обліку }\end{array}$
\end{tabular}

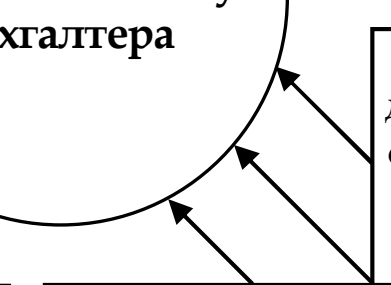

Забезпечення вимог держави та професійних організацій щодо змісту і форми навчального процесу

\begin{tabular}{|c|c|}
\hline Наукові розробки \\
3 питань розвитку \\
$\begin{array}{c}\text { бухгалтерської } \\
\text { професії }\end{array}$ & безперервного навчання \\
бухгалтерів \\
\hline
\end{tabular}

Навчальні заклади

\section{Рис. 2. Заходи щодо посилення професіоналізму бухгалтера}

Проблема професійної придатності та критеріїв ії̈ застосування до бухгалтерської професії $\epsilon$ не розробленою. Загальні вимоги до бухгалтера, передбачені у Кваліфрікаційному довіднику, не можуть розглядатися як умови, достатні для визначення придатності бухгалтера до обліково-аналітичної роботи і тим більше слугувати основою для прийняття рішення про успішність його діяльності в майбутньому.

Для встановлення домінуючого способу мислення виділено такі групи бухгалтерів: 
1. Бухгалтер-виконавець. Його діяльність складається 3 повторюваних дій, спрямованих на виконання вказівок бухгалтераорганізатора. Надає перевагу завданням які вимагають не ініціативності, а якості у роботі.

2. Бухгалтер-організатор. У структурі його діяльності переважають організаторські якості, йому подобається організовувати людей, давати їм завдання, інструктувати, приймати від них документи, узагальнювати їх. Такого бухгалтера доцільно використовувати як керівника бухгалтерської служби.

3. Бухгалтер-науковець. У його діяльності переважають реконструктивні якості: він любить вивчати складні й такі, що вимагають великої уваги й напруги, ситуації. Працює зазвичай поодинці, не бажає керувати людьми, не любить перевіряти незначні фракти, ретельно і в системі вивчає кожну операцію.

4. Бухаалтер-викладач. У його діяльності переважають комунікативні якості. Він товариський і легко вступає в розмову 3 незнайомими людьми. Улюбленою дією є надання пояснень.

Висновки. Розглядаючи критерії іміджу сучасного бухгалтера та значення бухгалтерської профресії в сучасному світі можна стверджувати, що бухгалтерська професійна діяльність як система визначається взаємозв'язками її структурних елементів: суб'єкта, дії, об’єкта. Виділення й обґрунтування трьох фрорм бухгалтерської професійної діяльності дозволяє розглядати діяльність трьох ключових осіб - бухгалтера-науковця, бухгалтера-викладача та бухгалтерапрактика - в контексті досягнення ними мети бухгалтерського обліку. При цьому бухгалтер-науковець розвиває теорію та методологію бухгалтерського обліку, бухгалтер-практик (організатор) - практику, а бухгалтер-викладач передає професійні знання, фрормує професійні 
навики та виховує професійні цінності у наступного покоління бухгалтерів-науковців, практиків, викладачів.

Різноманітність сфери діяльності бухгалтера та постійне її розширення призводить до необхідності оновлення змісту професії. Дослідження сфери діяльності бухгалтера в системі управління підприємством дало змогу зробити висновок про необхідність переходу на підготовку фахівця для декількох робочих місць, а не одного певного робочого місця.

Отже, необхідність відновлення довіри до контрольної фуннкції бухгалтерського обліку вимагає зміщення акцентів у діяльності бухгалтера на інтереси суспільства. Обслуговуючи своїх клієнтів, бухгалтер обслуговує суспільні інтереси, тому для відновлення довіри до фрінансової звітності центр уваги повинен бути зміщений у напрямі забезпечення більшої прозорості та відкритості бухгалтерської інформації. Соціальні процеси в розвитку бухгалтерської профресії полягають у зміні статусу працівника бухгалтерської служби, які проявляються у створенні високотехнологічних робочих місць і переході облікових функцій до контрольно-аналітичних.

\section{תimepamypa:}

1. Андрущенко В. (2007). Духовна сутність освіти. Вища освіта України: теоретичний та науково-методичний часопис. № 1 (24). С. 510.

2. Бакаев А.С. (2015). Регулирование бухгалтерского учета: роль государства и профессионального сообщества. Бухгалтерский учет. № 1. C. 5-10.

3. Білюшова Л.Є. (2003). Про окремі аспекти законодавчого 
забезпечення дотримання аудиторами принципів професійної етики. Аудитор України. № 13. С. 24.

4. Валуев Б. (2006). О недостаточной связи науки о бухгалтерском учете с проблемами развития целостной системы управления. Економіст. 12 грудня 2006. № 12. С. 58-63.

5. Василишин C.I. Трансформація місії та назви професії бухгалтера під впливом запитів зміцнення економічної безпеки підприємств в умовах діджиталізації економіки. Електронний ресурс. Режим доступу: http://magazine.faaf.org.ua/rozvitok-buhgalterskoi-profesii-v-umovahglobalizacii-svitovoi-ekonomiki.html

6. Голов С.Ф. (2004). Концепція профресійної освіти бухгалтера в України. Профресійна кваліфікація бухгалтерів: від вищої освіти до професійного визнання: Всеукраїнська конфреренція. Київ. Пуща Водиця, 28 травня 2004. С. 24-32.

7. Голов С.Ф. (2006). Парадигма конкурентоспроможного обліку. Школа профресійного бухгалтера. № 11 (71). С. 9-11.

8. Голов С.Ф. (2004). Предмет і метод бухгалтерського обліку: міфи та реалії. Облік і фрінанси АПК: Міжнародний науково-виробничий журнал. № 1. С. 17-23

9. Гусева Т.А.

(2006). Налоговое

планирование

B предпринимательской деятельности: правовое регулирование: Монография. М. Волтерс Клувер, 472 с.

10. Гуцайлюк 3. (2004). Ще раз про вдосконалення викладання бухгалтерського обліку в контексті Болонського процесу. Бухгалтерський облік і аудит. № 10. С. 31-32.

11. Джон Дейвіс. (2016). Відмивання грошей - нове середовище // Школа 
профресійного бухгалтера. № 5. С. 15.

12. Закон України “Про бухгалтерський облік та фрінансову звітність" Режим доступу: http://www.rada.gov.ua.

13. Ільюшина $€$. (2014). Глобалізація і постмодерне суспільство // Соціологія: теорія, методи, маркетинг. Жовтень-грудень 2014 . № 4. C. 57-78.

14. Канцуров О.О. (2016). Застосування термінології міжнародних стандартів бухгалтерського обліку у нормативно-правовій базі України. Фінанси України. № 8. С. 51-58.

15. Кірейцев Г.Г. (2007). Розвиток бухгалтерського обліку: теорія, профресія, міжпредметні зв'язки: Монографрія. Житомир. ЖДТУ. 236 с.

16. Кузьмінський Ю. (2013). Місце бухгалтера в управлінні економікою України. Бухгалтерський облік і аудит. № 5. С. 8-14.

17. Ловінська Л.Г., Стефранюк І.Б. (2016). Організація бухгалтерського обліку та фрінансового контролю в сучасних умовах господарювання в Україні. К. НДФІ. 240 с.

18. Малюга Н.М. (2005). Бухгалтерський облік в Україні: теорія й методологія, перспективи розвитку: Монографія. Житомир. ЖДТУ, 548 c.

19. Метелиця В.М. Розвиток бухгалтерської профресії в умовах глобалізації світової економіки. Електронний ресурс. Режим доступу: http://magazine.faaf.org.ua/rozvitok-buhgalterskoi-profesii-v-umovahglobalizacii-svitovoi-ekonomiki.html

20. Мних Є. (2005). Гармонізація міжнародних і національних стандартів освіти у підготовці фрахівців з обліку і аудиту в Україні // Бухгалтерський облік і аудит. № 12. С. 42-45. 
21. Панасюк В. М., Ковальчук Є. К., Мельничук І. В., Мужевич Н. В. (2020). Бухгалтерський облік: від знань до компетентностей [евидання]: навчальний посібник для дистанційного навчання. Тернопіль: [б. в.], 363 с.

22. Панасюк, В. М. (2020). Бухгалтерський облік [е-видання]: навч. посіб. В. М. Панасюк, І. В. Мельничук, Н. В. Мужевич. Тернопіль. THEY, $330 \mathrm{c}$.

\section{References:}

1. Andrushchenko V. (2007). Dukhovna sutnist osvity. Vyshcha osvita Ukrainy: teoretychnyi ta naukovo-metodychnyi chasopys. № 1 (24). S. 5-10.

2. Bakaev A.S. (2015). Rehulyrovanye bukhhalterskoho ucheta: rol hosudarstva y professyonalnoho soobshchestva. Bukhhalterskyi uchet. № 1. S. $5-10$.

3. Biliushova L.le. (2003). Pro okremi aspekty zakonodavchoho zabezpechennia dotrymannia audytoramy pryntsypiv profesiinoi etyky. Audytor Ukrainy. № 13. S. 24.

4. Valuev B. (2006). O nedostatochnoi sviazy nauky o bukhhalterskom uchete s problemamy razvytyia tselostnoi systemы upravlenyia. Ekonomist. 12 hrudnia 2006. № 12. S. 58-63.

5. Vasylyshyn S.I. Transformatsiia misii ta nazvy profesii bukhhaltera pid vplyvom zapytiv zmitsnennia ekonomichnoi bezpeky pidpryiemstv $v$ umovakh didzhytalizatsii ekonomiky. Elektronnyi resurs. Rezhym dostupu: http://magazine.faaf.org.ua/rozvitok-buhgalterskoi-profesii-v-umovahglobalizacii-svitovoi-ekonomiki.html

6. Holov S.F. (2004). Kontseptsiia profesiinoi osvity bukhhaltera v Ukrainy. Profesiina kvalifikatsiia bukhhalteriv: vid vyshchoi osvity do profesiinoho vyznannia: Vseukrainska konferentsiia. Kyiv. Pushcha Vodytsia, 28 travnia 
2004. S. $24-32$.

7. Holov S.F. (2006). Paradyhma konkurentospromozhnoho obliku. Shkola profesiinoho bukhhaltera. № 11 (71). S. 9-11.

8. Holov S.F. (2004). Predmet i metod bukhhalterskoho obliku: mify ta realii. Oblik i finansy APK: Mizhnarodnyi naukovo-vyrobnychyi zhurnal. № 1. S. $17-23$

9. Huseva T.A. (2006). Nalohovoe planyrovanye $v$ predprynymatelskoi deiatelnosty: pravovoe rehulyrovanye: Monohrafyia. M. Volters Kluver, 472 S.

10. Hutsailiuk Z. (2004). Shche raz pro vdoskonalennia vykladannia bukhhalterskoho obliku $v$ konteksti Bolonskoho protsesu. Bukhhalterskyi oblik i audyt. № 10. S. 31-32.

11. Dzhon Deivis. (2016). Vidmyvannia hroshei - nove seredovyshche // Shkola profesiinoho bukhhaltera. № 5. S. 15.

12. Zakon Ukrainy "Pro bukhhalterskyi oblik ta finansovu zvitnist" - Rezhym dostupu: http://www.rada.gov.ua.

13. Iliushyna Ye. (2014). Hlobalizatsiia i postmoderne suspilstvo // Sotsiolohiia: teoriia, metody, marketynh. Zhovten-hruden 2014. № 4. S. 57-78.

14. Kantsurov O.O. (2016). Zastosuvannia terminolohii mizhnarodnykh standartiv bukhhalterskoho obliku u normatyvno-pravovii bazi Ukrainy. Finansy Ukrainy. № 8. S. 51-58.

15. Kireitsev H.H. (2007). Rozvytok bukhhalterskoho obliku: teoriia, profesiia, mizhpredmetni zviazky: Monohrafiia. Zhytomyr. ZhDTU. $236 \mathrm{s.}$

16. Kuzminskyi Yu. (2013). Mistse bukhhaltera v upravlinni ekonomikoiu Ukrainy. Bukhhalterskyi oblik i audyt. № 5. S. 8-14.

17. Lovinska L.H., Stefaniuk I.B. (2016). Orhanizatsiia bukhhalterskoho 
obliku ta finansovoho kontroliu $v$ suchasnykh umovakh hospodariuvannia $v$ Ukraini. K. NDFI. 240 c.

18. Maliuha N.M. (2005). Bukhhalterskyi oblik v Ukraini: teoriia y metodolohiia, perspektyvy rozvytku: Monohrafiia. Zhytomyr. ZhDTU, 548 s.

19. Metelytsia V.M. Rozvytok bukhhalterskoi profesii $\mathrm{v}$ umovakh hlobalizatsii svitovoi ekonomiky. Elektronnyi resurs. Rezhym dostupu: http://magazine.faaf.org.ua/rozvitok-buhgalterskoi-profesii-v-umovahglobalizacii-svitovoi-ekonomiki.html

20. Mnykh Ye. (2005). Harmonizatsiia mizhnarodnykh i natsionalnykh standartiv osvity u pidhotovtsi fakhivtsiv z obliku i audytu $v$ Ukraini // Bukhhalterskyi oblik i audyt. № 12. S. 42-45.

21. Panasiuk V. M., Kovalchuk Ye. K., Melnychuk I. V., Muzhevych N. V. (2020). Bukhhalterskyi oblik: vid znan do kompetentnostei [e-vydannia]: navchalnyi posibnyk dlia dystantsiinoho navchannia. - Ternopil: [b. v.], 363 S.

22. Panasiuk, V. M. (2020). Bukhhalterskyi oblik [e-vydannia]: navch. posib. V. M. Panasiuk, I. V. Melnychuk, N. V. Muzhevych. Ternopil. TNEU, 330 s.

Citation: I. Danylyuk, V. Shuhmann (2021). THE PROFESSION OF "ACCOUNTANT" - FROM CRAFT TO MODERN SCIENCE. New York. TK Meganom LLC. Innovative Solutions in Modern Science. 3(47). doi: 10.26886/2414-634X.3(47)2021.1

Copyright: I. Danylyuk, V. Shuhmann ( ). 2021. This is an openaccess article distributed under the terms of the Creative Commons Attribution License (CC BY). The use, distribution or reproduction in other forums is permitted, provided the original author(s) or licensor are credited and that the original publication in this journal is cited, in accordance with accepted academic practice. No use, distribution or reproduction is permitted which does not comply with these terms. 